УДК: 811.163.41’38

811.163.41:929 Скерлић J.

DOI: https://doi.org/10.18485/belic_slv.2018.3.ch6

Галина Георгијевна Тјапко

\title{
КЊИЖЕВНО-ЈЕЗИЧКИ ПОЈАМ „БЕОГРАДСКИ СТИЛ” КОД ЈОВАНА СКЕРЛИТА
}

1. Историја српског књижевног језика је описана крајње неравномерно. Темељито је проучен концепт Вука Караџића који је фаворизовао језик руралне средине. Много мање су истражени почеци новог колосека српског књижевног језика у рано послевуковско раздобље, посебно првих деценија прошлог века, када Београд постаје центар српске духовности и културе, који је дао нови замах Вуковој реформи. У београдском књижевном поднебљу изњедрио се тада појам „београдски стил”. Један од првих (ако не и први) употребио је тај термин Јован Скерлић - златно перо српске књижевности и књижевне критике на рубу два претходна столећа. Израз београдски стил налазимо у његовој капиталној Историји нове српске књижевности (1914) која је резултат дванаестогодишњега наставничког, научног и књижевног рада Јована Скерлића. То животно дело заокружује његов кратак живот. Године зреле стваралачке активности књижевника трајале су тек деценију и по. Умро је млад, када му није било ни четрдесет година (родио се 1877, умро 1914), у напону снаге и зрелости свога талента.

У овом чланку ми ћемо се осврнути на Скерлићеву визију културноисторијских прилика које су еволуционирале у нову књижевно-језичку естетику урбане средине, његово поимање израза београдски стил, маркантне особине тог стила које је запазио код најистакнутијих књижевних радника свога времена. У монографији, коју овде разматрамо, Скерлић се показао не само као ненадмашени зналац историје српске књижевности, већ и као веома добар познавалац језичких прилика код Срба. Упоредо са прегледом културних и књижевних прилика дао је приказ језичких ситуација разних епоха.

Пишући о књижевности, Скерлић је потврдио органску повезаност литературе и језика. Дајући импозантан број портрета српских писаца разних књижевних и идејних праваца, струја и епоха, не заобилази ка- 
рактеристику језика и стила сваког од њих. Језик и стил писца је за Скерлића важно мерило у оцени његовог талента, књижевне писмености и квалитета књижевног дела.

2. Скерлић нигде не наводи своје поимање термина стил мада га користи више пута. Тај термин укоренио се у српској књижевности много пре настанка саме науке о стиловима - стилистици и није био у фокусу ондашње науке. Чинио се сасвим разумљивим Скерлићу и ондашњој читалачкој публици тако да није захтевао неко посебно тумачење. Из текста монографије следи да појам београдски стил у интерпретацији Скерлића има синтетичку природу и у једнакој мери припада језику и књижевности (књижевно-језички појам).

У савременој науци термин „стил” је веома дискутабилан и објашњава се различито. У овом раду полазимо од наједноставније дефиниције стила структуралистичке концепције која третира стил као девијацију или одступање (Гајда 2013: 26). Према тој концепцији „стил” се базира на контрастима: када се у текстовима нађу (супротстављају се) прогнозирани елементи са непредвидљивим, неочекиваним елементима. Њихов контраст подстиче, стимулише стил и ствара стилски ефекат. Према томе, феномен стила настаје од опозиције норме и одступања од ње - девијације. Екстраполација (проширивање) концепције стила као девијације на предмет овог излагања објашњава феномен београдског стила као опозицију концепту Вукове језичке реформе, као одступање од ње у књижевној пракси нове генерације књижевних радника на почетку XX века.

3. О београдском стилу као изазову канонима Вукове реформе Скерлић је проговорио тек у последњем поглављу своје опширне монографије, која се завршава прегледом српске књижевности у првој деценији XX века. (То је за њега најновије раздобље српске књижевности које је означио као „данашњу књижевност”. Добро ју је познавао јер је и сам био у њој личност првога реда). Међутим та антитеза пролази кроз сва раздобља Скерлићеве Историје нове српске книжевности, од почетка XVIII века.

Посматрајући развој нове српске књижевности као целине из своје временске перспективе - од почетка XVIII века, од писаца који чине спону између старе српске средњовековне, калуђерске писмености до најновијих аутора, који још пишу и развијају се, Скерлић издваја пет периода, које обележавају одређене духовне и књижевне правце:

$\checkmark \quad$ Рационализам (од почетка XVIII до, отприлике, 1810);

$\checkmark \quad$ Прелазно доба од рационализма ка романтизму (од 1810 до пред 1848); 
$\checkmark \quad$ Романтизам (1848 до, отприлике, 1870);

$\checkmark$ Реализам (1870-1900);

$\checkmark$ Данашња књижевност (за Скерлића је то прва деценија XX века).

Израз београдски стил Скерлић не употребљава кроз читав текст Историје: нема га ни у доба рационализма, ни у прелазно доба - од рационализма ка романтизму, ни у романтизму, ни у реализму. Али већ у поглављу о рационализму и јозефинизму - почетној фази нове српске књижевности - Скерлић припрема терен за образложење свог става o београдском стилу. Портретишући лик Доситеја Обрадовића, главне личности српске књижевности свога времена, Скерлић супротставља Доситејев трезвени и ведри рационализам романтичарским и „назадњашким заблудама" Вука Караџића и Омладине. У овом одељку има пуно заједљивих Скерлићевих примедби на рачун романтичара код којих „машта и осећање дошли су место разума, традиција место рефорама, култ прошлости место култа будућности" (Скерлић³ 1953: 96). Сучељавање идеологије рационализма и романтизма одјекује и у Скерлићево доба. Он констатује да после пада романтизма, од 1870. године, већ у доба реализма у српској књижевности, опет узимају маха рационалистичке идеје. Српски духови су се стали враћати Доситеју Обрадовићу. „И данас, - пише Скерлић, - духови деле се на два велика дела: на оне којима је родоначелник Доситеј Обрадовић са његовим широким рационалистичким, реалистичким и западњачким идејама, и на оне којима је родоначелник Вук Караџић са својим романтичарским и традиционалистичким идејама. [...] И одиста, данас после више од једнога века, - наставља Скерлић, - Обрадовић изгледа ближи, модернији, живљи од Вука Караџића, садашњост и стварност дају му за право, и зато је прослава његове стогодишњице 1911. узела размере једне велике националне прославе, и његов спомен прослављен као ничији досада" (Скерлић ${ }^{3}$ 1953: 97).

3.1. У критичком тоналитету описује Скерлић промене настале у доба романтизма, потпуно супротног идејама рационализма. Српски романтичари, будући под утицајем европских романтичара, устају против више класе, против трулог запада. Из језика се избацују речи туђинскога порекла. Идеализује се народни живот, село, задруга, народна поезија. Идеал романтичара је бити што ближи народу, осећати, говорити као он, живети као он, бити чист, сиров Србин, Србенда. Деци се почињу давати народна имена. Они који су при крштењу добили календарска имена окрећу их у народна. Ко се звао Ђорђе зове се Ђурђе или Ђурађ или Ђорђије; Димитрије постаје Дмитар или Гмитар; Тимотије Атанацковић 
постаје Богобој Атанацковић, Алексије Радичевић - Бранко Радичевић, Ђорђе Поповић - Ђуро Даничић, Коста Новаковић - Стојан Новаковић. Посрбљавају се и имена страних писаца: Фридрих Готлиб Клопшток постаје Љубомир Богољуб Клопшток. Посрбљавају се имена празника: Св. Георгије постаје Ђурђевдан, Јован Крститељ - Ивањдан, Вознесеније Спасовдан, Рождество Христово - Божић, Воскресеније - Ускрс. Почиње се носити или средњовековно одело, душанке и тазарице, или сељачко одело. Не зове се више господине, госпођо, госпођице, него брате Србине, сестро Српкиғо; место ви цео свет почиње говорити једно другом $m u$. Играју се народне игре, скупљају се и певају народне мелодије. У таквој атмосфери исковао је своју реформу српског књижевног језика Вук Стефановић Караџић.

Године 1868. Вуков правопис постаје званичан. Вук није затекао тај чин. Већ после његове смрти у складу са његовом реформом језик се чисти од страних речи и у томе пуританству иде се до крајности, до осиромашавања књижевног језика. Победиоци постају искључиви и неправедни. Чистоти језика даје се толико значаја да се књижевна дела врло често суде искључиво са језичке тачке гледишта. У то доба, - пише Скерлић, - многи писци су проглашени за велике само зато што су били присталице Вука Караџића, а извесни добри писци сасвим потиснути зато што су били противници простонароднога језика (в. Скерлић³ 1953: 255).

Скерлић је посебно скептичан када пише о месту Вука у српској књижевности. Сматрао је како и поред свих великих и несумњивих Вукових заслуга, данас се не може прихватити претерана Даничићева реч да је Караџић „отац нове српске књижевности”, из простога разлога што је пре њега, и у његово доба, и мимо њега, било добрих српских писаца и прогресивне српске књижевности. У чисто књижевном погледу, по мишљењу Скерлића, Вуков значај је мањи и више посредан него непосредан (в. Скерлић³ 1953: 261).

3.2. Седамдесете године XIX века обележене су у српској књижевности обновом рационализма. Само овај нови рационализам не ослања се толико на умовања „здравога разума” и апстрактне дедукције, колико на природне науке, на велике резултате које су оне постигле. Последица тога култа природних и егзактних наука била је да се безобзирно стао прогањати идеализам, романтизам, сентиментализам, све оно што је волео и у шта је веровао ранији нараштај. Тај тренд је дошао у српску књижевност под утицајем ондашње руске литературе. Не случајно Скерлић цитира једног руског писца како је у то доба „Рус нематеријалист био бела врана" (Скерлић ${ }^{3}$ 1953: 341). 
У реалистичком периоду од 1870. до 1900. године српска књижевност добија пространију културну област, постаје богатија родовима, садржајнија и савршенија формом. Књижевни језик се разрађује и развија и већ крајем деведесетих година српски стил је знатно богатији и књижевнији него што је био шездесетих година (в. Скерлић³ 1953: 349).

3.3. Почетком XX века дошло је до генерацијске промене у српској књижевности и прекида континуитета. Нестају стари и старији писци: смрт је проредила њихове редове, акумулисане управо у Београду. У првим годинама XX века умиру многи српски књижевници првога реда: 1901. Јован Илић, 1904. Јован Јовановић Змај, 1905. Јанко Веселиновић, 1906. Стеван Сремац, 1908. Милован Глишић, Симо Матавуљ, Радоје Домановић, 1910. Лаза Костић. Наместо писаца старије генерације јављају се у великом броју млади књижевни радници до јуче непознати. Никада пре у српској књижевности није радило тако мало старих а тако много младих писаца који су дошли са другим књижевним схватањима и још већом слободом у писању.

Дошло је и до промена генералних књижевних праваца. Старе књижевне школе су готово нестале. Романтизам, оспорен и ослабљен, у првој деценији XX века сасвим се изгубио. Реализам већ седамдесетих и осамдесетих година претходног столећа (пред крај XIX века) знатно се трансформирао, поставши у XX веку само једна успомена из прошлости. Сеоска приповетка, која је владала све до половине деведесетих година, из основа се променила или нестала. Утицај Војислава Илића, тако велики деведесетих година, изгубио се. Млади песници новог времена окренули су се сасвим другим узорима. Реализам с почетка XX века, уколико је уопште остао, добио је индивидуалистичко обележје. Модерни српски писци, констатује Скерлић, постају све особенији, оригиналнији, одређенији и већ своји. Очитује се њихов индивидуалистички карактер.

3.4. Почетком XX века у српској књижевности дошло је до новог заокрета према Европи. У погледу књижевних идеја и књижевне форме она све више постаје европска. Ранији књижевни утицаји све више слабе или сасвим нестају. Мађарски утицај сасвим се угасио. Немачки утицај ограничио се готово искључиво на Србе у Угарској, па и тамо слаби. Још увек доста, па и све више, пише Скерлић, осећа се руски утицај. У последње време примећује се да се укус српске читалачке публике опет враћа руским писцима, нарочито Толстоју, Тургењеву и Достојевском, који се поново и обилно преводе и све више читају. У појединим књижевним делима, нарочито у социјалној драми, видљив је утицај руских писаца. Али ипак тај утицај није у српској књижевности толико општи и тако снажан као што је био седамдесетих година XIX века. 
3.5. Место свих тих ранијих утицаја у српској књижевности све јаче осећа се утицај француске културе и француске књижевности, који узима маха после повратка прве генерације (око 1848) домаћих синова школованих у Француској, оних које су звали „Паризлије”.

Француски утицај није био ограничен само на превођење француских књига и приказивање француских комада. Од краја деведесетих година француски утицај се јако осећао и у оригиналној књижевној производњи, нарочито у лирици и у књижевној критици, нешто мање у роману. Српски књижевни стил се успешно преображава према великом француском узору. Интерпункција, која је доскоро према немачком била граматичка, сада према француском постаје логична.

3.6. У усавршавању књижевног језика и стила Скерлић види једну од најважнијих одлика општега напретка у српској књижевности у почетку $\mathrm{XX}$ века. Поздрављајући свеже снаге у српској градској књижевности, Скерлић рано сахрањује Вукову реформу. Према њему, стара филолошка школа сасвим се изгубила са својим ненаучним и преживелим схватањима: да је српски књижевни језик довршио своје развијање и да је језик Вука Караџића и Ђура Даничића дефинитиван књижевни језик од кога ce, као од неке светиње, не сме одступати. Данас је опште примљено (!) схватање да је књижевни језик један жив организам, природан и спонтан производ вазда усавршљивог људског духа и да се као такав мора развијати, попуњујући се позајмицама сваке врсте, и оживљеним згодним архаизмима и примањем лепо казаних (!) провинцијализама, нарочито прихватањем спонтано посталих неологизама, и да за нове идеје и нова осећања потребни су и нови изрази и нове форме (в. Скерлић $\left.{ }^{3} 1953: 434\right)$. Ко би то оспоравао?

Претераном критиком Вукових погледа Скерлић је наставио ону полемику коју су своједобно водили савременици Вука Караџића, некадашњи опоненти његове реформе. У половини XIX века, - пише Скерлић, - мислило се да је језик којим су Караџић и Даничић превели Библију идеалан српски језик, а писци су писали према тим узорима. Међутим упркос свему источно наречје сачувало је у данашњој српској књижевности свој ранији положај зато што има традицију, зато што је краће, лакше, пословније (!), енергичније, уједначеније, емотивно закључује Скерлић. Даље следи закључак о формирању у почетку XX века ни више ни мање, него новог књижевног језика.

У Србији, у Београду, у чисто националној средини, далеко од туђих утицаја, у општој и свестраној употреби коју језику може да да само једна чисто национална држава, ствара се нов књижевни језик, слободан, жив, крепак, гибак, живописан, увек у покрету и у стварању. Тај тако названи 
београдски стил, у реакцији против раније филолошке школе и у презирању (!) догматичке граматике и у тежњи за оригиналним изражавањем, каткада иде сувише далеко. Али и поред неизбеживих крајности и злоупотреба, он је једна велика тековина и елемент напретка у данашғој (у почетку XX века) српској књижевности. Он, пун снаге и живота, прелази границе Србије и намеће се целој књижевности нашега језика [...]. Никада се у српској књижевности није књижевније писало но што данас у доба завлађивања „београдског стила”, закључује Скерлић (Скерлић ${ }^{3}$ 1953: 435).

4. Појам „београдски стил” упућује на урбану средину, главни град Србије која је неколико векова под Турцима била културна пустош. Од XIV века склањајући се од турске навале Срби су стално повлачили свој духовни и културни центар према северу, дошавши до Беча који је постао најсевернији центар српске духовне активности све до краја XVIII века. Кад је касније турска царевина почела губити територије, српски центар се помиче према југу: око 1825. центар се премешта у Пешту, од четрдесетих година улогу Српске Атине почиње преузимати Нови Сад. Од седамдесетих година српска духовна хегемонија прелази на Београд. Од почетка седамдесетих година Нови Сад, стара „Српска Атина” почео је губити хегемонију, и Београд постаје српско духовно средиште. Пре тога, пише Скерлић (Скерлић ${ }^{3}$ 1953: 345), сви духовни покрети српски прелазили су од угарских Срба у Србију, од седамдесетих година идеје се почињу из Србије ширити на остале српске крајеве.

До седамдесетих година главни српски писци били су родом из Угарске. Од седамдесетих и осамдесетих година XIX века, главни српски писци су већ из Србије: Милован Глишић, Лаза Лазаревић, Јанко Веселиновић, Војислав Илић. У Србију долазе најважнији српски писци рођени ван њених граница: Јован Јовановић Змај, Лаза Костић, Симо Матавуљ, Стеван Сремац.

Јачање Београда који је преузео улогу нове „Српске Атине” подстиче београдску тему у српској књижевности на рубу два претходна века која полако истискује сеоску проблематику. Реакција Скерлића није једнозначна. Са великим интересовањем, љубоморно, као истинити патриота Београда прати књижевна дела, посвећена београдској проблематици, али веома ретко дели похвале њиховим ауторима, посебно због језика којим су написана. Београд је велика кушња за књижевнике, једне уништава, а реткима даје бесмртност.

Тако се Јанко Веселиновић, када је дошао у варош, помео, збунио, и почео падати. Београд га је разоравао. Радио је много и све, постао је жртва издавача, радио је брзо преко колена, почео је да пише развучено, 
изгубио је своју оригиналност. Стил му је постао немаран, фразеолошки, новинарски. Када је покушао да слика београдски живот у Циганчету и Мору без приморја, могло се видети колико га је варош помела и ослабила (Скерлић³ 1953: 372).

Ништа боље није прошао код Скерлића и Симо Матавуљ, мада га је назвао најобразованијим међу српским приповедачима. Скерлић замера Матавуљу неистинитост описа Београда због тога што није из Београда. Ових десет-петнаест година које је живео у Београду нису му биле довољне да осети и проникне све особености београдског живота. „[...] Може Матавуљ још двадесет година седети у Београду, са најбољом вољом, са највећим талентом, и са најпотпунијом књижевном спремом, он никада неће моћи осетити оне интимне, танане преливе који чине одлику београдског живота. За пуно ствари он неће имати очију, многи звуци неће наћи одјека у његовој души, и он ће у опису Београда вазда опомињати на странца који је добро научио српски језик, али без осећања језика и са туђим нагласком.” Покушавајући ублажити критику, Скерлић закључује да су Београдске приче занимљиве и читке, и свакако једна од најбољих књига што нам је прошла година дала. [...] Само, поред свега, и после његове књиге, наш Београд има још да чека свога моралнога историка" (Скерлић 1955: 299).

Једини сликар београдског живота пред којим Скерлић скида капу је Милутин Ускоковић, новелист по узору модерних француских писаца, аутор романа Дошљаци. У овом добром делу, - пише Скерлић, - Ускоковић је успео у оном у чему су сасвим промашили писци као Јанко Веселиновић и Симо Матавуљ, у сликању савременог престоничког живота. У Доитацима он је дао [...] тачне слике разних београдских средина, поремећени живот у младој престоници, грозничаву борбу у једном још неорганизованом друштву, лепе и живе описе београдског пејзажа. Поред тога у роману има добрих психолошких опажања, способности да се дају анализе сложених појава модерне душе. Скерлић посебно истиче приповедачки таленат Ускоковића, његов леп књижевни стил и занимљиво причање.

Посебан допринос београдском стилу дала је најновија српска поезија у лику Јована Дучића и Милана Ракића. Говорећи о језичкој вештини Дучића у његовим путописима, Скерлић не штеди похвале: „то је писано нечувено сјајним, блештавим стилом, богатим речником и ретким фигурама, са много духа и грације, са толико литературе да читалац остаје засењен” (Скерлић ${ }^{3}$ 1953: 437). Првенство са Дучићем по праву дели Милан Ракић. Његови стихови, звонки и чисти, одјекују звеком племенитог метала (Скерлић $1953: 439)$. 
Скерлић с правом истиче допринос српске књижевне критике, која је напредовала од краја деведесетих година XIX века, а посебно у XX веку под утицајем модерне француске књижевне критике. Далеко књижевнија но што је икада била, рађена са књижевним укусом и осећањем, нарочито писана пажљивим модерним кюижевним стилом, она утиче и непосредним примером и знатно је помогла подизању књижевнога мерила и стварағу једног књижевног стила (Скерлић ${ }^{3}$ 1953: 434).

Пишући о језику и стилу Богдана Поповића, књижевног критичара првог реда, Скерлић још једном спомиње израз „београдски стил”: „Васпитан у најбољој књижевној школи и код најбољих писаца, са урођеним списатељским способностима, он [Поповић] је отпочео писати књижевним, новим, живописним и духовитим, али јасним и крепким стилом, који је доцније добио име „београдског стила”. [...] Он је дао примере доброг књижевног писања и у том погледу повео за собом цео један низ нових писаца" (Скерлић³ 1953: 460).

Скерлић високо оцењује и вештину писања Слободана Јовановића, правника и социолога који је дао изванредне узоре књижевног стила у стручним текстовима. Одликујући се од готово свих писаца своје струке, уских стручњака без општег и књижевног образовања, који не полажу никакву пажњу на форму и језик, Јовановић је своје стручне послове радио у врло књижевној форми, отменим стилом и изврсним језиком (Скерлић 1953: 461).

Огроман допринос београдском стилу дао је и сам Јован Скерлић. Својим емотивним писањем никога није остављао равнодушним. Он је показао и доказао како настанак тог стила у новој српској књижевности није случајна појава него резултат двовековне еволуције интелектуалне мисли код Срба у потрази за савршенијим обликом изражавања. Из његове монографије следи да је формирање београдског стила узроковано низом фактора:

1. У току два века нове српске књижевности у XVIII веку (за Скерлића је то прва деценија XX века) дошло је до конфронтације и размимоилажења између западњачких идеја рационализма и домаћих, руралних вредности, потакнутих немачким романтизмом, у које се потпуно уклапала језичка реформа Вука Караџића. Скерлић поштује Вука, али очито га не воли: често је необјективан према њему, емотиван и пренагљен у критици. Још мање воли филологе који спутавају језик догматски следећи Вукову граматику.

2. Управо је Београд изнедрио нови књижевни стил као алтернативу ранијој филолошкој школи јер почетком XX века постаје не- 
оспорно српско духовно средиште које привлачи најбоље књижевне раднике укључујући и оне који су рођени ван Србије.

3. На појаву новог начина изражавања утицао је донекле и прекид континуитета у списатељској средини. Почетком XX века дошло је до потпуне генерацијске обнове: смрт је готово обезглавила српску књижевност акумулисану управо у Београду. Млади књижевни радници до јуче непознати дошли су са другим књижевним схватањима и још већом слободом у писању.

4. У српској књижевности долази до новог заокрета према Европи. За разлику од романтизма и реализма у којима су главну улогу играли домаћи фактори, почетком XX века првенство задобијају француски утицаји. Они захватају најпре критику и поезију, а затим и прозу. У књижевни рад укључују се 'Паризлије', домаћи синови, школовани у Француској.

5. Једна од кључних одлика књижевног језика XX века у односу на језик Вука Караџића је његова интелектуализованост. За разлику од језика Вука Караџића београдски стил је пре свега језик урбане целине који је стварно обогатио српски језик и дао је нови замах његовом развитку.

Говорећи о посебном београдском стилу, Скерлић у ствари даје само своју емотивну оцену те нове појаве. Његова заслуга што ју је уочио, чак и означио терминолошки као београдски стил, временски и историјски образложио као књижевно-језичку појаву новога времена. По свој прилици, више и није могао да учини, јер је био књижевни радник а не језикословац. Међутим, својом капиталном Историјом нове српске книжевности, својим открићем београдског стила није задужио само стручњаке за књижевност, него и језикословце који проучавају историју српског књижевног језика и магију београдског стила.

\section{ИЗВОРИ}

Скерлић ${ }^{3}$ 1953: Ј. Скерлић, Историја нове српске књижевности, Београд: Рад. Скерлић 1955: J. Скерлић, Писии и књиге, књ. II, Београд: Просвета. 


\section{ЛИТЕРАТУРА}

Гајда 2013: С. Гайда, Что такое стиль?, у: Стилистика как речеведение: сб. науч. тр. славянских стилистов, посвященный памяти М.Н. Кожиной / под ред. Л.Р. Дускаевой, Москва: ФЛИНТА - Наука, 25-34.

Галина Георгиевна Тяпко

\section{О ЛИТЕРАТУРНО-ЯЗЫКОВОМ ПОНЯТИИ „БЕЛГРАДСКИЙ СТИЛЬ У ЙОВАНА СКЕРЛИЧА}

Резюме

Среди ранних употреблений термина „белградский стиль” почетное место принадлежит капитальной монографии Йована Скерлича „История новой сербской литературы” (1914), определившей проблематику данной статьи. Возобновившийся интерес к исследованию феномена белградского стиля мотивирован новым этапом нормализации сербского языка в условиях независимого развития, восстановлением всех его составляющих на разных этапах функционирования.

Несмотря на то, что монография Й. Скерлича была написана в начале прошлого века, многое из ее содержания не утратило актуальности и поныне. В предложенной Скерличем периодизации первостепенное значение имеет характеристика историко-культурной и языковой ситуации, определяющей литературные направления и писательский корпус разных эпох. Выделяя ключевые личности сербской литературной истории, Скерлич большое внимание уделяет анализу языка и стиля писателей. Наивысшей оценки удостаиваются редкие авторы, современники Скерлича, создававшие блестящие тексты свободным, индивидуальным стилем, нарушая прескрипции Вука Караджича. Анализ показал, что для Скерлича понятие „белградский стиль” является синтетическим, литературно-языковым понятием.

В статье определены факторы, способствовавшие формированию белградского стиля, обозначившего новую траекторию в развитии сербского литературного языка: (1) перемещение в Белград центра сербской духовной и культурной жизни; (2) влияние городского уклада жизни на литературное творчество; (3) высокая концентрация авторского контингента; (4) резкая смена поколений в писательском корпусе; (5) европеизация сербской литературы; (5) приход в литературу молодых талантов, получивших образование в Европе, прежде всего во Франции. 
В статье понятие „стиля” определяется как антитеза нормы и отклонения от нее (девиация). Эта антитеза имплицитно проходит через все периоды Истории новой сербской литературы, получая окончательное воплощение в заключительной главе монографии Скерлича, который, надо признать, необоснованно противопоставляет белградский стиль языку Вука Караджича, как два разных литературных языка, не видя в них разные фазы развития одного и того же идиома. 